\title{
Qual o Seu Diagnóstico?
}

\section{Múltiplas Pápulas na Face}

Filipa Tavares Almeida?', Regina Caldas' , Ana Patrícia Rodrigues², Olga Ferreira' ${ }^{1}$

'Hospital De Braga, Department of Dermatovenereology, Braga, Portugal

${ }^{2}$ Hospital De Braga, Department of Surgical Pathology, Braga, Portugal

PALAVRAS-CHAVE - Neoplasias Faciais/diagnóstico; Neoplasias da Pele/diagnóstico.

\section{Dermatology Quiz}

\section{Multiple Papules on the Face}

KEY WORDS - Facial Neoplasms/diagnosis; Skin Neoplasms/diagnosis.

\section{CASE REPORT}

A 43-year-old female patient was referred to our department due to multiple painless skin colored firm papules and nodules, with a smooth surface, ranging from a few millimeters to $2 \mathrm{~cm}$, located on the face, particularly around the nose and forehead, and scalp, in this latter location causing alopecia. Lesions developed progressively over 12 years (Fig. 1). There were no complaints from other organs and she was under no chronic medication. The patient reported her mother had similar skin lesions that also started around the age of 30 .

An excisional biopsy of a skin nodule of the scalp was performed and histological examination showed a dermal

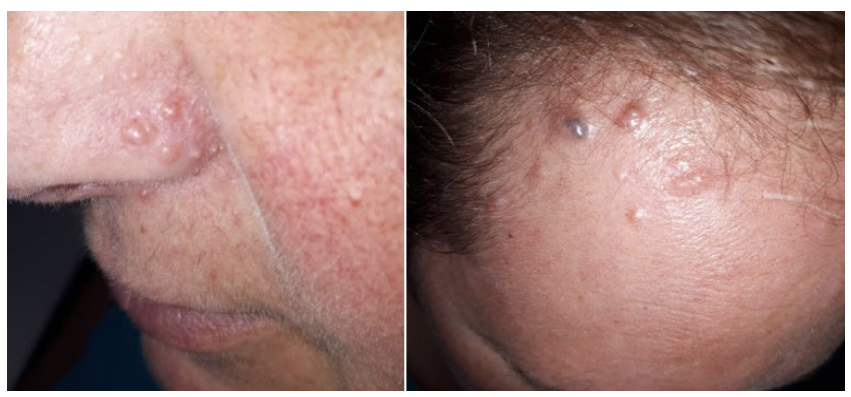

Figure 1 - Multiple skin colored papules and nodules located on the face.
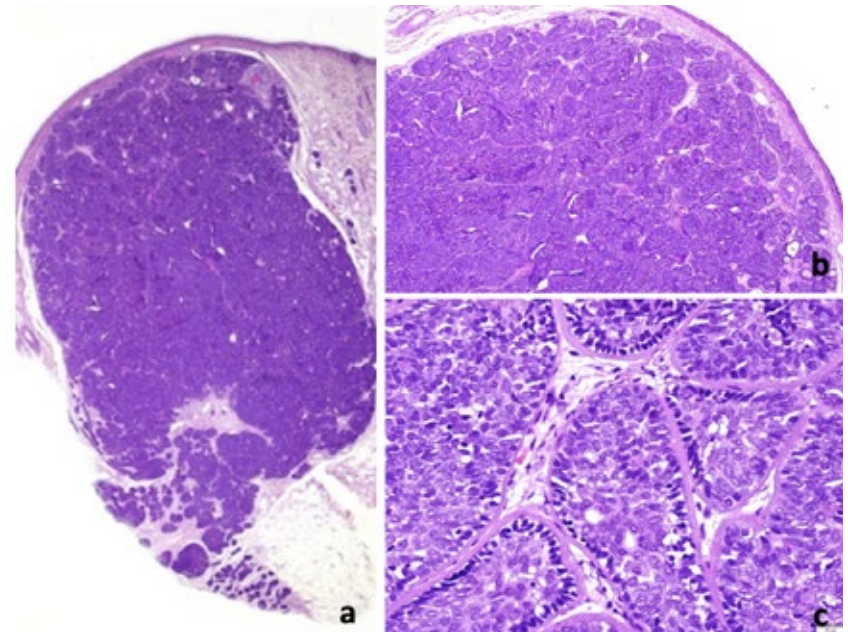

Figure $\mathbf{2}$ - Dermal lesions composed by multiple lobules arranged in a jigsaw pattern typical of cylindroma (image a, H\&E, 20x and image b, $\mathrm{H} \& \mathrm{E}, 40 \mathrm{x})$. Each lobule consists of an outer layer of cells with small hyperchromatic nuclei and an inner zone of cells with oval vesicular nuclei, surrounded by a hyaline mantle (image c, H\&E, 400x).

lesion composed by multiple lobules arranged in a jigsaw pattern. Each lobule consisted of an outer layer of cells with small hyperchromatic nuclei and an inner zone of cells with oval vesicular nuclei, surrounded by a hyaline mantle (Fig. 2). Genetic study showed a heterozygous nonsense mutation (c.2806C > T, p.Arg936*) of the CYLD gene.
Correspondência: Filipa Tavares Almeida Sete Fontes

4710-243 Braga, Portugal

T.:00351912438376

E-mail: Filipa.almeida6@hotmail.com

DOI: https://dx.doi.org/10.29021/spdv.78.1.1127 2020/04/--

(c) Autor (es) (ou seu (s) empregador (es)) e Revista SPDV 2020. Reutilização permitida de acordo com CC BY-NC. Nenhuma reutilização comercial.

(c) Author(s) (or their employer(s)) and SPDV Journal 2020. Re-use permitted under CC BY-NC. No commercial re-use. 


\section{WHAT IS YOUR DIAGNOSIS?}

\section{BROOKE-SPIEGLER SYNDROME}

Clinical and histological findings combined with family history suggested Brooke-Spiegler syndrome and the genetic test confirmed the diagnosis. Due to the absence of symptomatic complains or aesthetic concerns, the patient refused treatment procedures.

No suspicious lesions were identified during 5 years of follow-up.

Brooke-Spiegler syndrome (BSS) is a rare genodermatosis, with an autosomal dominant pattern of inheritance, caused by mutations in the CYLD gene, a tumor suppressor gene. ${ }^{1}$ It is characterized by the development of multiple skin appendage tumors, namely spiradenomas, cylindromas and trichoepitheliomas. ${ }^{2}$ Although they are typically benign, malignant transformation occurs in $5 \%$ to $10 \%$ of the patients. ${ }^{3}$ In such cases mostly cylindrocarcinomas develop within the lesions. Less frequently, malignant spiradenomas and basal cell carcinomas were described. ${ }^{4}$ Apart from the skin, morphologically similar neoplasms may rarely arise in the salivary glands or breasts (mammary cylindroma). ${ }^{5}$

This case highlights the importance of skin lesions as a diagnostic clue for systemic diseases. A prompt diagnosis enables the genetic counseling of the patient and his relatives, through a multidisciplinary approach, allowing the early detection of the underlying malignancies, namely malignant transformation of cutaneous lesions and salivary glands tumors. ${ }^{6}$

\section{Presentations/Apresentações}

Poster presentation on 24th World Congress of Dermatology 2019.

Conflitos de interesse: Os autores declaram a inexistência de conflitos de interesse na realização do presente trabalho.

Fontes de financiamento: Não existiram fontes externas de financiamento para a realização deste artigo.

Confidencialidade dos dados: Os autores declaram ter seguido os protocolos da sua instituição acerca da publicação dos dados de doentes.

Consentimento: Consentimento do tutor legal para publicação obtido.

Proveniência e revisão por pares: Não comissionado; revisão externa por pares.
Conflicts of interest: The authors have no conflicts of interest to declare.

Financing support: This work has not received any contribution, grant or scholarship.

Confidentiality of data: The authors declare that they have followed the protocols of their work center on the publication of data from patients.

Patient Consent: Consent for publication was obtained.

Provenance and peer review: Not commissioned; externally peer reviewed

\section{ORCID}

Filipa Tavares Almeida

https://orcid.org/0000-0001-6561-5338

Regina Caldas

https://orcid.org/0000-0002-6921-7916

Ana Patrícia Rodrigues

https://orcid.org/0000-0002-9043-4587

Olga Ferreira

https://orcid.org/0000-0001-7160-0626

\section{REFERENCES}

1. Pinho AC, Gouveia MJ, Gameiro AR, Cardoso JC, Gonçalo MM. Brooke-Spiegler Syndrome - an underrecognized cause of multiple familial scalp tumors: report of a new germline mutation. J Dermatol Case Rep. 2015;9: 67-70. doi: 10.3315/jdcr.2015.1208.

2. Manchanda K, Bansal M, Bhayana AA, Pandey S. Brooke-Spiegler syndrome: a rare entity. Int J Trichology 2012; 4: 29-31. doi: 10.4103/0974-7753.96084.

3. Kazakov DV. Brooke-Spiegler Syndrome and phenotypic variants: an update. Head Neck Pathol. 2016; 10:125-30. doi: 10.1007/s12105-016-0705-x.

4. Mohiuddin W, Laun J, Cruse W. Brooke-Spiegler Syndrome. Eplasty. 2018; 18:ic14.

5. Scott AR, Faquin WC, Deschler DG. Parotid mass in a woman with multiple cutaneous cylindromas. Head Neck. 2010;32:684-7. doi: 10.1002/hed.21133.

6. Lavorato FG, Miller MD, Obadia DL, Nery NS, Silva RS. Syndrome in question. Brooke-Spiegler syndrome. An Bras Dermatol. 2014; 89:175-6. doi: 10.1590/ abd1806-4841.20142194. 